\title{
Gastrointestinal Arteriovenous Malformation
}

National Cancer Institute

\section{Source}

National Cancer Institute. Gastrointestinal Arteriovenous Malformation. NCI Thesaurus.

Code C35515.

An abnormal connection between arteries and veins, occurring within the vasculature of the gastrointestinal tract. 